要

約

“甘味葡萄酒の糖分を倉沢氏等のペーパー法で検出し一般分析の結果と比較対照した。

文献

1）穂積 - 佐藤: 本誌, 45 巻, 325 頁 (昭 25)

"2) 伊藤・渡辺：" 47468 " (" 27)

\title{
Detection of sugars in sweet wines by paper partition chromatography
}

\section{H. Muto and K. Tonegawa}

(Received Jan. 10, 1954)

\section{Summary}

Sucrose, fructose and glucose are clearly and easily separated and detected by Kurasawa's xmethod by using butanol-ethanol-water developer, anilin-hydrochloride reagent and orcine reaagent (for ketoses).

\section{清 酒 貯 藏 試 驗}

光線及び酵素による各種成分の変化について

風間雍

（昭和 29 年 1 月 10 日受理）

緒 言

一般酒造物は後熟作用が大きな意義を有しその成分及び品質が変化し向上したり時には変質する。後者

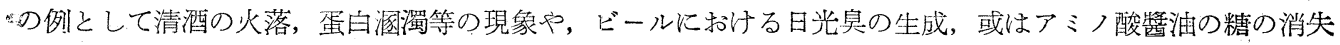

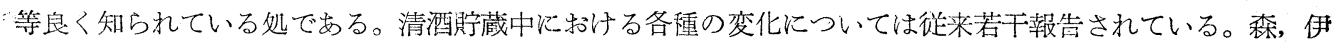

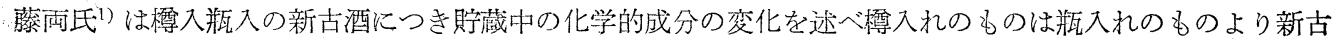
酒共に変化甚だしく, 又瓶入れのものは新古酒共 Alcohol, Sugar, Dextrin 等を減じ其の他の成分の增 加を認め, 高橋氏2 (3) $^{3}$ は清酒貯蔵中 Amino acid 含量と火落現象の関係を論じ, 又山田, 浦野両氏 ${ }^{4}$ (樽詰 、酒につき Aldehyde の推移を述べ, 田中, 芝田, 伊藤氏等 ついて黑野, 肥田両氏 $\left.{ }^{6}\right)$ 山田, 立野両氏77 加藤, 鈴木両氏 $\left.{ }^{8}\right)$ は主に糖化酵素につき清酒品質との関係を述べ ている。筆者は清酒の貯蔵中に抢ける光線及、び酵素による各種成分の変化につき若干の試験をし, 三三の結 果をえたので報告する。

\section{実験}

\section{:(1) 供詿酒の調製及び貯蔵条件}

昭和 27 年度二級原酒一種をえらび Table 1 に示す如く容器の種類により二つに大別し, 更にそれ等の “各区を火入れの有無により二群に分けた。乃ち容器は全て瓶を用い, 清酒用青色 4 合瓶 (I区), 及び市販二 ホンビールの褐色透明瓶（川区）に分け，更に各区共火入れせずに瓶詰しコルク栓を附したものを、群とし 瓶詰後 $60^{\circ} \mathrm{C} 5$ 分間処理の火入れをし殺菌コルク栓を附し貯蔵せるものをb洋とした。

以上総計 4 本の試験酒を薬品棚中に収め室温 $\max 33^{\circ} \mathrm{C}, \min , 15^{\circ} \mathrm{C}$ 飞て貯わ兄以下の方法飞基いて分析 試験を行つた。尙本試験品は日光の直射をさけ自然の光にさらしておらた。

Table 1 試験清酒の䝪藏条件

\begin{tabular}{|c|c|c|c|c|c|}
\hline 区 分 & 容器の種類 & 火入れの有無 & 区 分 & 容器の種類 & 火入の有無 \\
\hline I $\quad \begin{array}{l}\mathrm{a} \\
\mathrm{b}\end{array}$ & 青色瓶 & $\begin{array}{l}\text { 無 } \\
\text { 有 }\end{array}$ & II $\quad \begin{array}{l}a \\
b\end{array}$ & 褞色䤠 & $\begin{array}{l}\text { 無 } \\
\text { 有 }\end{array}$ \\
\hline
\end{tabular}




\section{（2）貯蔵酒の分析方法}

町蔵酒の分析は昭和 28 年 4 月 28 日（火入貯蔵開始の日）より原則として 1 月に 1 回計 5 回実施し陚料 (約 $100 \mathrm{cc}$ ) は各瓶より無菌的にとり次の方法で分析した。
(イ) Sake meter
: 常法による。
(ㅁ) $\mathrm{pH}$
：東洋濾紙製 $\mathrm{pH}$ 試験紙 B.C.G. Kよる。
(八) Acid
: 試料 10 cc につき B.T.B: N.R. mixed indicator を用い N/10 NaOH
$\Leftrightarrow$ Amino acid で滴定しその $\mathrm{cc}$ 数で示す。

\section{(ホ) Total sugar}
(へ) Sugar
(ト) Dextrin
: 試料 $10 \mathrm{cc}$ につき Formol method により N/10 NaOH で滴定しそのcc 数で示す。
：常法により酸糖化後 Lane's method にて糖を定量し Glucose として示 す。
：試料そのままを Lane's method により定量し Glusose として示す。
: 常法により酸糖化後 Lane's method にて糖を定量し前項の直糖を隇じた ものに 0.9 を乘じて示す。
（チ） Alcohol : $\mathrm{K}_{2} \mathrm{Cr}_{2} \mathrm{O}_{7}$ 酸化法による。
(リ) Amylase activity : $2 \%$ Sobuble Starch $50 \mathrm{cc}$ (Mc Ilvain buffer にて pH 4.8 に規整せる 6の）飞試料清酒 $5 \mathrm{cc}$, toluotl 2 滴, 蒸溜水 $25 \mathrm{cc}$ を加兄 $55^{\circ} \mathrm{C}$ にて糖 化経時的に試料を $10 \mathrm{cc}$ とり $\mathrm{NaOH}$ とて直ちに䤃素作用を止め, 生成せ る糖分をWillstatter-Schudel 法にて測定し作用直後の $\mathrm{N} / 10 \mathrm{Na}_{2} \mathrm{~S}_{2} \mathrm{O}_{3}$ 滴定数より各時間後の $\mathrm{N} / 10 \mathrm{Na}_{2} \mathrm{~S}_{2} \mathrm{~S}_{3}$ 滴定数を隇じた值を以つて示した。

佾上記各成分円他 Protease activity について試験したが顕著な結果が出ず, 又 Paper chromatogram により Amino acid の種類の推移を検討したが判然とした差を認めず, ここには省略する。各成分の分析

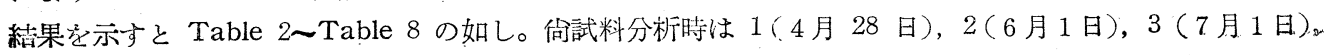
4 (8月1日), 5 (10月1日) であつた。

Table 2 Sake meter

\begin{tabular}{|c|c|c|c|}
\hline & \multirow{2}{*}{$\sim_{b}$} & \multicolumn{2}{|c|}{ II } \\
\hline$a$ & & a & b \\
\hline \pm 1.7 & 王1.7 & 王1.7 & $\mp 1.7$ \\
\hline \pm 0.9 & $\mp 1.4$ & $\mp 1.4$ & \pm 0.8 \\
\hline 王1.7 & $\mp 1.0$ & $\mp 0.7$ & $\mp 0.7$ \\
\hline I1. 5 & $\mp 1.5$ & $\mp 1.5$ & \pm 1.0 \\
\hline 王1.4 & \pm 0.9 & $\equiv 0.1$ & $\equiv 0.6$ \\
\hline
\end{tabular}

Table 4 Amino acid (cc)

$\begin{array}{lllll}1 & 0.21 & 0.20 & 0.19 & 0.20 \\ 2 & 0.18 & 0.19 & 0.19 & 0.18 \\ 3 & 0.17 & 0.17 & 0.17 & 0.17 \\ 4 & 0.20 & 0.18 & 0.20 & 0.19 \\ 5 & 0.21 & 0.20 & 0.21 & 0.20\end{array}$

Table 3 Acid (CC)

\begin{tabular}{llll}
$\overbrace{0.13}^{\mathrm{a}}$ & 0.14 & & \multicolumn{2}{c}{ II } & $\overbrace{0.13}^{\mathrm{a}}$ & 0.13 \\
0.15 & 0.15 & 0.15 & 0.15 \\
0.15 & 0.14 & 0.14 & 0.14 \\
0.13 & 0.12 & 0.12 & 0.12 \\
0.12 & 0.13 & 0.12 & 0.12
\end{tabular}

Table 5 Total sugar (\%)

$\begin{array}{llll}4.12 & 4.07 & 4.18 & 4.18 \\ 4.41 & 4.30 & 4.41 & 4.36 \\ 4.26 & 4.24 & 4.29 & 4.17 \\ 4.02 & 4.00 & 4.13 & 4.00 \\ 3.88 & 3.84 & 3.91 & 3.98\end{array}$

Table 6 Sugar $(\%)$

（）内は Sugar/Total Sugar

$\begin{array}{lll}1 & \overbrace{3.00(0.728)}^{\mathrm{a}} & \overbrace{3.01(0.740)}^{\mathrm{b}} \\ 2 & 3.78(0.857) & 3.57(0.830) \\ 3 & 3.84(0.901) & 3.56(0.840) \\ 4 & 3.66(0.910) & 3.38(0.845) \\ 5 & 3.61(0.930) & 3.25(0.846)\end{array}$

$\begin{array}{ll}\overbrace{3.12(0.746)}^{\mathrm{a}} & \overbrace{3.12(0.746)}^{\mathrm{b}} \\ 3.71(0.841) & 3.49(0.800) \\ 3.75(0.874) & 3.56(0.870) \\ 3.63(0.879) & 3.38(0.846) \\ 3.52(0.900) & 3.30(0.829)\end{array}$


Table 7 Dextrin (\%) （）内は Dextrin/Total Sugar

$\begin{array}{lllll}1 & 1.01(0.245) & 0.95(0.233) & 0.95(0.226) & 0.95(0.226) \\ 2 & 0.57(0.129) & 0.70(0.163) & 0.63(0.143) & 0.79(0.181) \\ 3 & 0.38(0.089) & 0.62(0.146) & 0.49(0.114) & 0.55(0.132) \\ 4 & 0.32(0.076) & 0.56(0.140) & 0.45(0.109) & 0.56(0.140) \\ 5 & 0.25(0.064) & 0.53(0.138) & 0.35(0.090) & 0.61(0.153)\end{array}$

Tabe 8 Amylase activity (cc)
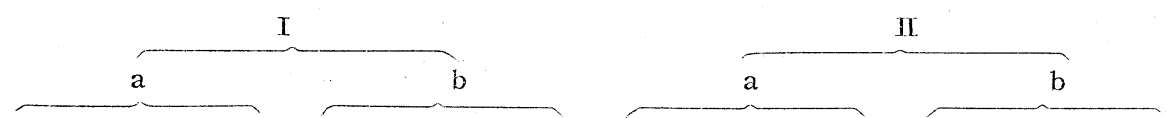

after $1 \mathrm{~h}$. after $3 \mathrm{~h}$. after $1 \mathrm{~h}$. after $3 \mathrm{~h}$. after $1 \mathrm{~h}$. after $3 \mathrm{~h}$. after $1 \mathrm{~h}$. after $3 \mathrm{~h}$.

$\begin{array}{lllllllll}1 & 1.65 & 2.90 & 0.15 & 0.10 & 1.75 & 3.00 & 0.30 & 0.10 \\ 2 & 1.34 & 2.68 & 0 & 0 & 1.19 & 2.48 & 0 & 0 \\ 3 & 1.45 & 2.85 & 0 & 0 & 1.35 & 2.05 & 0 & 0.10 \\ 4 & 0.40 & 0.55 & 0 & 0 & 0.50 & 0.80 & 0 & 0.10 \\ 5 & 0.10 & 0.65 & 0 & 0 & 0 & 0.70 & 0.50 & 0.85\end{array}$

考察

\section{1. 成分の変化について}

以上の分析結果から各成分の変化を考察してみるとまず Sak'e meter は陚験開始後 3 ケ月目まではそれ

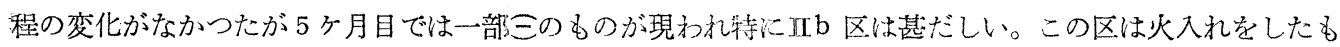
のであるが, Table 8 に示す如くAmylase activity 多多残り, 又 Table 7 に和计る Dextrin の最終 分析では他に比して多く出ているためと考光られる。 $\mathrm{pH}$ は常に 4.2 学示し変化していない。Acid 3 ケ 月目に綕体的に増加したかにみえたが著しいものではなく又旧に復しだ。Amino acid の変化は若干みられ る様でありこれにつき高橋氏は細菌醭素によると述べ本問题については更に検討したい。Sugar 及び Dex-

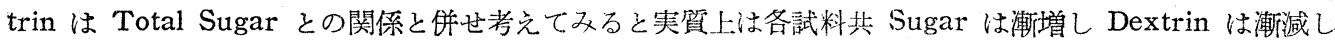
ている。但しIIb のそれらの值が若干変調を示している。つ京り $\mathrm{S} / \mathrm{T}, \mathrm{D} / \mathrm{T}$ の各值を他と比較するときと Table 2, Table 8 と併せ考察与ると火入れの不完全がその原因の一つと考兄られる。Alcohol の変化はみ

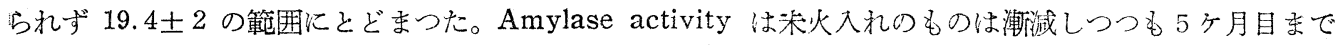
は完全に残存した。

\section{2. 品啠の変化について}

瓶詰眝蔵は長期に亘る場合適切でない事は從来より知られており瓶香汇よる変筫, 光線による変化等種 々 ある。本実験においては青色瓶䝪蔵の（区の二点は共に甚だしく変質し，香味極端にだれ色調は甚だしく赤 褐変した。之に反し褐色瓶斯蔵の川区の二点は前二者に比し其に香味落ちず色調の変化はにとんどみられず 良好であつた。

\section{要旨}

1. 清酒眝蔵の変化につき火入条件脈び容器の差異に基づく影響を検討した。

2. 青色瓶貯蔵区は変質著るしくこれは光線によるもので醉素によるものでない。

3. Amino acid, Sugar，Dextrin の念量は䤏素により変化するが他の成分は余り变化せず，その程度 は概してח区はエ区より緩慢にみられる。

\section{交献}

1）森，伊藤：酫協誌 31, 1094 (昭11) [原報同誌 8 号]

2) 高橋：醉劦誌 32,240 (昭12) [原報, 酸試報 39 号]

3）同上：同上, 357 (同上)〔原報, 同上 49 号〕

4) 山田, 浦野: 醉協誌 33, 327 (昭13)

5）田中，芝田，伊藤：羉協誌。34, 662（昭14）

6) 黒野, 肥田：䂅協誌 $28,(10) 1$ (昭 8)

7) 山田, 立野: 鑾協誌 33,328 (昭13) 
8）加藤，鈴木：醸協誌 46,334 (昭26)

(荻城県醸造試験所)

\section{Studies on the storage of Saké.}

On the change of some components by light and remaining enzymes.

\section{Y. Kazama}

(Received Jan. 10, 1954)

\section{Summary}

The change of some components of sake was investigated during the storage with the follow-.ing results :

(1) The influences of light and enzymes during the storage were observed.

(2) Sake stored in the blue-glass bottles was denatured strongly not by enzymes but by light.

(3) The contents of amino acids, sngars and dextrin changed by enzyme action, and the changes were greater in the Group I than in the Group II.

\section{東北地方に於ける醬油について（第2 報） \\ 秋田県産醬油の品質について \\ 蔀花雄・小賏戶和夫・神谷真太郎 \\ （昭和 28 年 12 月 11 日受理）}

前報1)に引続き秋田県に於ける農業協同組合及び業者の製品 46 点について分析し, その化学的組成, 色 調, 香味及び価格の点について検討したのでその結果を報告する。秋田県に於ては山形県と異り農協の锤造 工場は 3 工場に過ぎず 46 点中農協製品は 5 点で 41 点は業者製品であつた。試料蒐集に御協力を戴いた秋 田県経済部農政課，秋田県味憎醬油工業協同組合及び試料を提供された生産者の各位に対し梁く感謝の意を 表する。

\section{1. 実 験 方 法}

\section{(1) 化 学 分 析}

1. 比重 $\mathrm{B}^{\prime} \mathrm{e}\left(15^{\circ} \mathrm{C}\right)$

2. エキス 醬油屈折計に依つた

3. 全窒素 キェルダール法

4. アミノ態窒素 フォルモール法

5. 全糖分 加水分解後ミクロベルトラン法に依り glucose として算出した

6. 還元糖 ミクロベルトラン法

7. 総 酸 フェノールフタレンを指示薬として N/10 前性ソーダにて滴定し乳酸として算出した

8. 食 塩 モール氏法

\section{(2) 鑑 評}

当所職員 5 名で行つた。味 60 点, 香 30 点, 色 10 点满点として採点しその平均值を揭げた。

\section{2. 分. 析 結 果}

分析結果は試料 $100 \mathrm{cc}$ 中の重量\%で示した。 